\title{
Entre fotografia e cinema: Ruy Santos e o documentário militante no Brasil dos anos 1940
}

\author{
Maria Teresa Bastos'
}

Maria Guiomar Ramos ${ }^{2}$

1. Professora adjunta da Escola de Comunicação da UFRJ. Pós-doutorada em Comunicação e Cultura pela ECO/NFRJ (2011). Doutorado em Letras/Estudos de Literatura pela PUC-Rio (2007). E-mail: bastos.te@gmail.com

2. Professora Adjunta da Escola de Comunicações da Universidade Federal do Rio de Janeiro. Doutorado em Estudos Cinematográficos e Audiovisuais pela Escola de Comunicações e Artes da Universidade de São Paulo (2002). E-mail: guiguiomarramos@yahoo.com.br 


\section{Resumo}

Ruy Santos (1916-1989), fotógrafo e cineasta que dirigiu filmes de ficção e documentários, é um dos expoentes do cinema militante de esquerda brasileiro, surgido nos anos 1940. Sua obra permitiu o cruzamento explícito entre cinema e ideologia que, de alguma maneira, antecipou e contribuiu para o nascimento do cinema engajado posterior. Carioca e comunista, Ruy Santos tem uma grande atuação também como fotógrafo. Foi preso pela polícia política brasileira em 1948 e teve a maior parte de sua produção fotográfica apreendida, material que hoje se encontra preservado pelo Arquivo Público do Estado do Rio de Janeiro. Já no início de seu percurso profissional funda, em 1945, com Oscar Niemeyer e João Tinoco de Freitas, uma produtora ligada ao Partido Comunista Brasileiro, a Liberdade Filmes, produzindo três documentários: Comício: São Paulo a Luís Carlos Prestes (1945), Marcha para a democracia (sobre as viagens de Prestes pelo Brasil, 1945) e 24 anos de luta (sobre a história do PCB, 1947). O primeiro deles é motivo de análise deste artigo.

\section{Palavras-chave}

Cinema militante, fotografia, comunismo, arquivo 


\section{Abstract}

Ruy Santos (1916-1989), photographer, film and documentary director, is one of the exponents of the leftist Brazilian militant cinema which emerged in the 1940s. His work allowed the explicit intersection between film and ideology somehow anticipating and contributing to the birth of a later engaged cinema. A carioca and a communist, Ruy Santos had a great production also as a photographer. He was arrested by Brazilian political police in 1948 and had most of his photographic work apprehended, now preserved by the Public Archive of the State of Rio de Janeiro. Early in his career, in 1945, he founded Liberdade Filmes along with Oscar Niemeyer and João Tinoco de Freitas, a producer conected to the Brazilian communist party, producing three documentaries: Comício: São Paulo a Luís Carlos Prestes (1945), Marcha para a democracia (on the trails of Luís Carlos Prestes in Brazil, 1945) and 24 anos de luta (about the history of the PCB, 1947). The first mentioned documentary is analyzed in the present article.

\section{Keywords}

Militant cinema, photography, communism, archive 
Muito se fala do cinema engajado no Brasil, identificado com o final dos anos 1950 através dos filmes de ficção com tendência esquerdista, como Rio 40 e depois com os documentários cinemanovistas de Leon Hirszman, Wladimir Carvalho, Paulo César Saraceni, Linduarte Noronha, Joaquim Pedro de Andrade e Geraldo Sarno. Mas desde os anos 40 é possível apontar para o surgimento de um cinema militante de esquerda, onde há o cruzamento explícito entre cinema e ideologia. Tal cruzamento, de alguma maneira, antecipou e contribuiu para a projeção do cinema engajado que viria posteriormente.

Nesse contexto, destaca-se Ruy Santos (1916 - 1989), importante cineasta e fotógrafo brasileiro que já no início de seu percurso profissional funda, em 1945, com Oscar Niemeyer e João Tinoco de Freitas, uma produtora ligada ao Partido Comunista Brasileiro (PCB), a Liberdade Filmes, produzindo três documentários: Comício: São Paulo a Luiz Carlos Prestes (1945), Marcha para a democracia (sobre as viagens de Prestes pelo Brasil, 1945) e 24 anos de luta (sobre a história do PCB, 1947).

Ruy Santos, nascido em 1916, foi fotógrafo e cineasta com extensa trajetória como fotógrafo de ficção, atuando em conhecidas produções como $O$ malandro e a grã-fina (1947), de Luiz de Barros; Sol sobre a lama (1963), de Alex Vianny e O saci (1951 e 1953), de Rodolfo Nany. Dirigiu alguns longas-metragens como, na década de 1960, A doce mulher amada (uma adaptação da obra de Máximo Gorki) e, em 1977, O desconhecido (uma adaptação da obra de Lúcio Cardoso), entre outras.

Desde muito moço Santos teve contato com o cinema brasileiro ao ser assistente de câmera de Edgar Brasil no clássico Limite (1930). Trabalhou como técnico de laboratório e foi assistente de câmera na Cinédia (em 1936 ele assume a fotografia de exteriores do filme Maria Bonita, dirigido pelo francês Julien Mandel). Ainda nos anos 1930 entra para o Partido Comunista onde realiza algumas experiências cinematográficas junto ao produtor João Tinoco de Freitas $^{3}$ realizando dois documentários de curta metragem incluindo as músicas de Dorival Caymmi A jangada e Itapuã. 
Nos filmes de ficção, Ruy Santos trabalha como câmera em Alma e corpo de uma raça (1938), de Milton Rodrigues. Na década de 1940 também faz o trabalho de câmera em Pureza (1940), de Chianca Garcia e em Inconfidência Mineira (1948), de Carmem Santos e de fotografia em O Homem que chutou a consciência (1947), de Ruy Costa.

Em 1939 entra para o Departamento de Imprensa e Propaganda (DIP), órgão de propaganda da ditadura de Getúlio Vargas, que representava uma forma de inserção em uma das poucas estruturas de produção acessíveis na época. No DIP já havia uma infiltração de membros do partido, como era o caso de Moacyr Fenelon e de Nelson Schultz. Além disso, de acordo com documentação encontrada pelo pesquisador e curador da Cinemateca do Museu de Arte Moderna do Rio de Janeiro, Hernani Heffner, havia um filme de Ruy Santos chamado Favela, fotografado e dirigido por ele. Para o DIP, tinha a função de propagandear os esforços do governo do Getúlio em acabar com a miséria, mas que, vindos de um comunista como Santos, poderiam significar uma forma de influência ideológica nos órgãos reacionários do Estado $\mathrm{Novo}^{4}$. Seus filmes mais conhecidos realizado nessa fase em que estava no DIP, que é quando se firma como documentarista, são os curtas Debret e o Rio de hoje, Terra seca, Dança e As missões.

Ruy Santos também realiza, já na década de 1950, os curtas A casa de Mário de Andrade, A batalha dos transportes e Anatomia do progresso. Em 1954, convidado por Joris Ivens, Ruy Santos dirige a parte brasileira do documentário O canto dos rios, uma produção da ex-Alemanha Oriental. Além dos filmes de ficção, Ruy fotografou e dirigiu mais de trinta documentários, dos quais alguns foram premiados no Brasil e no exterior. Apesar de uma extensa cinematografia, o diretor não é conhecido pelo grande público. Este artigo pretende cobrir essa

4. Heffner, em conversa com as autoras, afirma que a referência sobre este filme de Ruy Santos tem duas fontes: "a primeira foi um recorte de jornal manuseado na Cinédia nos anos 80 e que menciona este filme, indicando que ele fotografou e dirigiu Favella. O recorte era de 1939. A outra fonte referia-se a intervenções no subúrbio (o que o governo fez para acabar com a miséria, etc). Ele mencionava o filme sobre a Providência filmado por Humberto Mauro no Favella dos meus Amores, e pelo Leon Hirszman, no episódio Pedreira de São Diogo e incluído no Cinco Vezes Favela. O filme também se referia ao cais do porto, na mesma região, possivelmente como um espaço que desenvolveria o entorno ou como uma área atingida pela miséria." 
lacuna trazendo à tona não só seu percurso como documentarista, período entre os anos de 1945 e 1947, quando dirige três filmes para o PCB, como também destacar seu olhar de cineasta político-militante, além do aspecto especificamente fotográfico de sua concepção fílmica.

Pensando na trajetória do diretor até os anos 1940 como sendo marcada pela ideia de uma possível relação de influência do PCB sobre a sociedade através do cinema, podemos localizá-lo, em 1945, como o profissional escolhido para realizar três filmes do partido - então na legalidade - assumidamente militantes: Comício: São Paulo a Luiz Carlos Prestes e Marcha para a democracia e Vinte quatro anos de lutas. Esse momento é crucial para o Partido Comunista. Ruy Santos conseguiu registrar em imagens essa transformação, uma vez que elas demonstravam uma mudança de organização: originariamente composto por militantes profissionais, clandestinos ou semi-clandestinos, tornava-se agora um partido de massas, legalizado, reestruturado e voltado para a grande multidão. E mais, as imagens de Ruy Santos registram o PCB de Luiz Carlos Prestes no exato momento em que ele desponta para o futuro como o "cavaleiro da esperança", a grande liderança para o povo.

Esses três documentários registram o momento em que o PCB se voltava para a mística de Prestes, quando ele passou a ser uma referência para a multidão que comparecia aos comícios. Essas imagens são representativas de um momento particular da história do PCB que, ao longo de seus setenta anos de existência, permaneceu mais tempo na ilegalidade do que com plenos direitos políticos. As imagens retratam através do olhar peculiar de Ruy Santos um dos momentos de legalidade do partido, marcado pelos paradoxos da defesa pública da União Nacional no governo Getúlio Vargas, dos primeiros meses após a libertação de Prestes ocorrida em abril de 1945 e das novas orientações políticas.

Ruy Santos foi preso em 27 de abril de 1948 pela polícia política brasileira ${ }^{5}$ - atuante no Brasil entre 1920 e 1983 -, quando grande parte do seu acervo foi apreendida. Essa informação está documentada num recorte do jornal

5. Desde 1992, o Arquivo Público do Estado do Rio de Janeiro é o guardião de vasta documentação produzida e apreendida pela implacável e obsessiva policia política brasileira, atuante por mais de sessenta anos no controle e repressão da sociedade. 
ano 2 número 3

Dossiê

Diário Carioca, arquivado pela Polícia com data de 28 de abril de 1948. Os recortes de jornais foram uma das práticas desenvolvidas pela polícia para acompanhar e controlar suspeitos. Grande parte da massa documental encontrada no acervo da polícia política é constituída por esta espécie de clipping rotineiro realizado pelos policiais.

O PCB foi considerado um dos maiores "inimigos internos" da polícia política brasileira e, com isso, os comunistas foram alvos de suspeita, investigação e, consequentemente, de documentação. O nascimento da policia política brasileira coincide com o do partido comunista brasileiro ${ }^{6}$ e, desta forma, cada passo dado pelos "vermelhos", como eram chamados pela Policia, era devidamente acompanhado pelo olhar observador dos policiais.

\section{Do comício em si e da realização do Filme $O$ comício: São Paulo a Luiz Carlos Prestes (9 minutos e 14 segundos, 1945)}

Quando, em 19 de abril de 1945, as portas da cadeia se abriram para deixar sair Luiz Carlos Prestes, o legendário cavaleiro da esperança, beneficiado pela decretação da Anistia anunciada no dia anterior, o Partido Comunista parecia viver uma nova aurora, em que todos os sonhos eram permitidos. O comentário do historiador Daniel Aarão Reis descreve bem o clima que os comunistas almejavam conseguir com a realização de um comício no Estádio do Pacaembu, em São Paulo, e nos outros dois estádios do Maracanã, no Rio de Janeiro, e em Recife, marcando a aparição do grande líder.

Este comício seria realizado apenas dois meses depois da legalização do partido e da saída de Prestes da prisão, onde permanecera por 10 anos, desde o episódio da chamada Intentona Comunista em 1935, quando sua mulher Olga Benário fora extraditada para um campo de concentração nazista e ali morta.

6. "O Partido Comunista, Seção Brasileira da Internacional Comunista (PC-SBIC), foi fundado num congresso realizado nos dias 25, 26 e 27 de março de 1922. As duas primeiras sessões tiveram lugar no estado do Rio de Janeiro, no Sindicato dos Alfaiates e dos Metalúrgicos, e a reunião final foi realizada na residência da família de Astrogildo Pereira, na rua Visconde do Rio Branco 651, em Niterói" (PANDOLFI, 1995, p.70). 
Impressiona a quantidade de pessoas presentes e a forma organizada como elas comparecem ao evento. Mas o partido já estava bastante articulado desde o Congresso da Mantiqueira, um encontro feito às escondidas em 1943, quando Prestes, mesmo estando na prisão, foi eleito como secretário do partido. Além deste comício, foram realizadas uma série de outros grandes encontros entre Prestes e o povo em estádios de futebol lotados, como o comício organizado no Rio de Janeiro e em Recife.

O fim da II Guerra Mundial, a anistia geral aos presos - que se aplicou a Prestes -, e a legalização do partido, reúnem e expandem a participação não só de intelectuais já filiados a partidos políticos, como outras camadas da população. No comício realizado em São Paulo temos a participação de Pablo Neruda, Monteiro Lobato, Jorge Amado, Graciliano Ramos, Astrogildo Pereira e Miguel Costa (companheiro de Prestes desde a Coluna Invicta, ocorrida em 1924), além de outros grupos organizados. Desses, um era a Federação de Mulheres. Elas se reuniram durante dois meses na casa das irmãs Guiomar e Brites Rocha Álvares, membros do partido. A casa das jovens havia sido escolhida como ponto de encontro por ser menos visada. Encontravam-se também no cine República, local alugado pelo partido para reuniões com grande quantidade de pessoas, justamente para poderem preparar o comício ${ }^{7}$.

Até aquele momento Prestes era um mito para todos, pois mesmo os militantes do partido não o conheciam. Ele era o mito sem face. Nunca havia realmente aparecido em público, já que sua participação nos momentos mais importantes da política brasileira não havia sido muito divulgada até então. Prestes pertencia ao "subterrâneo da sociedade". Sua participação na malograda "Intentona comunista" fora preparada em silêncio e fora do Brasil. Seus contatos primeiro eram com Moscou e, depois disso, ficou preso durante 10 anos $^{8}$.

7. Informação obtida em 2009 através de entrevista a Guiomar Rocha Álvares, hoje já falecida, na época com 101 anos de idade.

8. Não eram conhecidas as poucas imagens de Prestes como líder da Coluna que leva seu nome e atravessou o Brasil pregando uma revolução. Ele se ausenta da revolução de 1930 por discordar das diretrizes tomadas por seus integrantes e, nos poucos cine-jornais e filmes da época, aparece sempre a figura de Getúlio. 
Isso significa que Prestes era o grande líder esperado, e o PCB, naquele momento, no Brasil e no mundo inteiro, era o local para onde os intelectuais convergiam, já que a atuação dos comunistas na resistência ao nazi-fascismo trouxera imenso prestígio aos Partidos Comunistas de todo o mundo. O cinema, por outro lado, poderia ser usado pela primeira vez por um partido que se acostumara a expor suas ideias através de recursos indiretos e escondidos - como já foi mencionado em relação ao cinema e pode ser visto também através da imprensa e da literatura. O partido tinha o líder e poderia, finalmente, usar o cinema para expor suas ideias e estratégias.

Por isso, além deste curta, foi realizado, também em 1945, pela Liberdade Filmes com financiamento do partido e do jornal A tribuna popular, outro curta intitulado A Marcha de Prestes. Ele que acompanhou uma campanha do líder Luís Carlos Presentes pelo Brasil. E em 1947, foi realizado o longa 24 anos de lut $a^{9}$, que completa a trilogia de pretender fazer triunfar o nome de Prestes talvez até como presidente da República

\section{Do filme}

Para melhor analisar o filme Comício: São Paulo a Luiz Carlos Prestes o dividimos em quatro partes: os créditos, os preparativos para o comício, o dia do comício, a chegada de Prestes e os desfiles.

Logo no início da sequência dos créditos lê-se a frase "Um filme do Partido Comunista do Brasil, realização do Comitê do Partido Comunista", seguida dos símbolos da foice e do martelo - que não mais aparecerão em nenhum outro momento -, além do crédito do estúdio (Estúdios Cinédia, produtora que talvez estivesse envolvida apenas em um momento de pós-produção), do narrador, do autor do texto narrado e do diretor e fotógrafo (Ruy Santos). Não são mencionados o nome de João Tinoco, produtor executivo, e da produtora Liberdade Filmes. Sobre essa questão vale a pena retomar a observação feita por

9. O longa foi perdido, resta dele um roteiro que está sob as guardas do APERJ. O assunto será desenvolvido mais à frente deste texto. 
Heffner afirmando que a ausência do nome da Liberdade Filmes "talvez fosse uma prática comum aos filmes militantes, e o destaque à Cinédia, que aparece também como distribuidora, por outro lado, fosse uma estratégia de se inserir no mercado cinematográfico".

A sequência dos preparativos pode ser sintetizada como "a cidade espera o comício". Seria formada pelos blocos de imagens com os intelectuais de "peso", usando intertítulos de uma mensagem de Monteiro Lobato que saudava o Cavaleiro da Esperança. O poeta chileno Pablo Neruda surge escrevendo em uma mesa, rodeado de pessoas, acompanhado por uma voz over que anuncia que ele pertence ao Partido Comunista e escreve um poema em homenagem a Prestes. Temos também, como representação da expectativa em torno da chegada do grande líder, close sobre cartazes nos muros da cidade anunciando o comício. Homens e mulheres trabalham fazendo painéis, cartazes e faixas de propaganda e realizando as preparações mesmo: estas imagens representam quase 1/3 do filme, 2 minutos e 58 segundos de um total de 9 minutos.

A voz over destaca a contribuição de estudantes, operários e pintores de São Paulo nos preparativos. Mostra-se a estátua de Davi com o Estádio do Pacaembu ao fundo, vazio. Novamente de uma voz over acompanhando diz: “a véspera de um grande dia de festa do proletariado". Em seguida, vemos a imagem de trabalhadores estendendo faixas e uma voz over complementa com as palavras de ordem: unidade, democracia e progresso.

O terceiro ponto destacado no curta refere-se às imagens do dia de realização do grande evento. Um close sobre a estátua de Davi, um travelling sobre a arquibancada onde um grupo de operários come sanduíches no mesmo ritmo. Então a voz over muda completamente para um tom coloquial: "E se chegamos tão cedo... vamos garantir o estômago e distrair as ideias". A imagem de mulheres na arquibancada é acompanhada pela voz over que anuncia: “camponesas também querem ouvir a voz de Prestes". As cenas de camponeses foram para Ruy Santos imagens de extrema importância. Em entrevista a Alex Viany, realizada em 1980, ele comenta que acompanhou os camponeses desde a saída de casa, às 5 horas da manhã, e não os perdeu de vista no estádio. 
Na quarta parte, destaca-se a imagem do desfile de comitês e organizações ano 2 número 3 do partido presentificada pelos cartazes que identificam os grupos ali presentes, como os operários com os cartazes onde lemos: "trabalhadores da Pirelli saúdam Prestes". Há uma ênfase na alternância de takes do desfile com aqueles da plateia, seguidos de uma panorâmica do estádio lotado, complementado pela voz over com o texto: “(...) é um espetáculo jamais visto".

O clímax desta última parte é a chegada de Prestes, momento em que são exibidas a bandeira nacional e pessoas na arquibancada saudando o líder. Os planos com a imagem de Prestes são alternados ora com as imagens da multidão, ora com a figura de Miguel Costa, líder da coluna Prestes, e do poeta Pablo Neruda. A narração anuncia a presença de cada um que está ali, mas o nome de Jorge Amado não é mencionado. Em seguida, passa-se para imagens do povo e para um close do rosto do Cavaleiro da Esperança. Por breves momentos temos o som direto da voz do grande líder que discursa, com o contracampo das imagens do povo.

A maneira como a imagem de Prestes é colocada em primeiro plano, antes de o vermos discursando sobre o palanque, insinua aproximações com outros filmes de propaganda política dos anos 1930, em particular com o conhecido filme de propaganda nazista: O triunfo da vontade, de Leni Riefenstahl (1934). E, guardadas as devidas proporções em relação à produção e o tempo de filme - aqui temos um curta-metragem de 9 minutos enquanto $O$ triunfo da vontade é um longa de quase duas horas -, podemos apontar alguns procedimentos semelhantes. O filme aproveita o encontro de grandes dimensões populares, como foi o congresso nacional-socialista alemão de 1934, para caracterizar o poder do líder nazista sobre as massas organizadas. O curta O comício acontece a partir do encontro marcado entre Prestes, outros grandes líderes comunistas e comissões populares organizadas para recebê-lo e demonstrar apoio.

Um dos procedimentos utilizados pela diretora para destacar a imagem de Hitler foi mostrá-lo em campo e contracampo, junto à multidão que o aclama, criando a imagem de um diálogo possível. Prestes também é destacado diversas vezes em planos onde é contraposto à multidão que o aclama. Ambos os filmes caracterizam de maneira bem clara as diferentes classes sociais que 
apoiam o líder, como o grupo dos operários, dos camponeses, e no caso de O comício, dos intelectuais. Do discurso de Prestes, como também em vários momentos do discurso de Hitler, algumas palavras de ordem são destacadas para serem repetidas como "unidade, democracia e progresso" e, no Triunfo da vontade, "um povo, um líder".

Existe um ponto determinante para o filme Comício que não existe no Triunfo da vontade, e que marca a grande diferença de propósito entre os dois, é a importância da sequência relativa aos preparativos do grande evento. A imagemsigno do construir é tão ou mais importante do que a chegada de Prestes. Esta opção de linguagem explica o que realmente diferencia as duas produções: $O$ Triunfo da vontade é claramente um filme de propaganda porque Hitler já está no poder e, assim, o filme representa uma ostentação da sua vitória, enquanto o filme de Ruy Santos simboliza uma militância em direção à conquista do poder.

\section{Cinema militante}

Pode-se pensar que o documentário de Ruy Santos torna-se Militante não exatamente através das opções de linguagem aqui exibidas, mas em função do contexto histórico no qual ele se insere. A participação efetiva de intelectuais como o poeta Pablo Neruda e os escritores Monteiro Lobato e Jorge Amado, que surgem no filme, além do próprio Santos e Oscar Niemeyer, produtores, são exemplos de um outro tipo de relação entre cinema e sociedade. Ao representar diretamente o Partido Comunista, ele mostra um tipo de engajamento, explicitado pelo discurso fílmico, que em nada se assemelha às produções de propaganda política.

Isso evidencia-se também pelo destaque dado, através de dois planos, à estátua de Davi, situada em frente ao estádio do Pacaembu. Podemos remetê-la à história bíblica, representativa do poder do homem pequeno contra o gigante, que simboliza a possibilidade de derrocada do grande poder capitalista pelos pequenos. A serenidade, convicção e ao mesmo tempo coragem e vitória de Davi sobre o gigante Golias é emblemática da luta contra o poder instituído. 


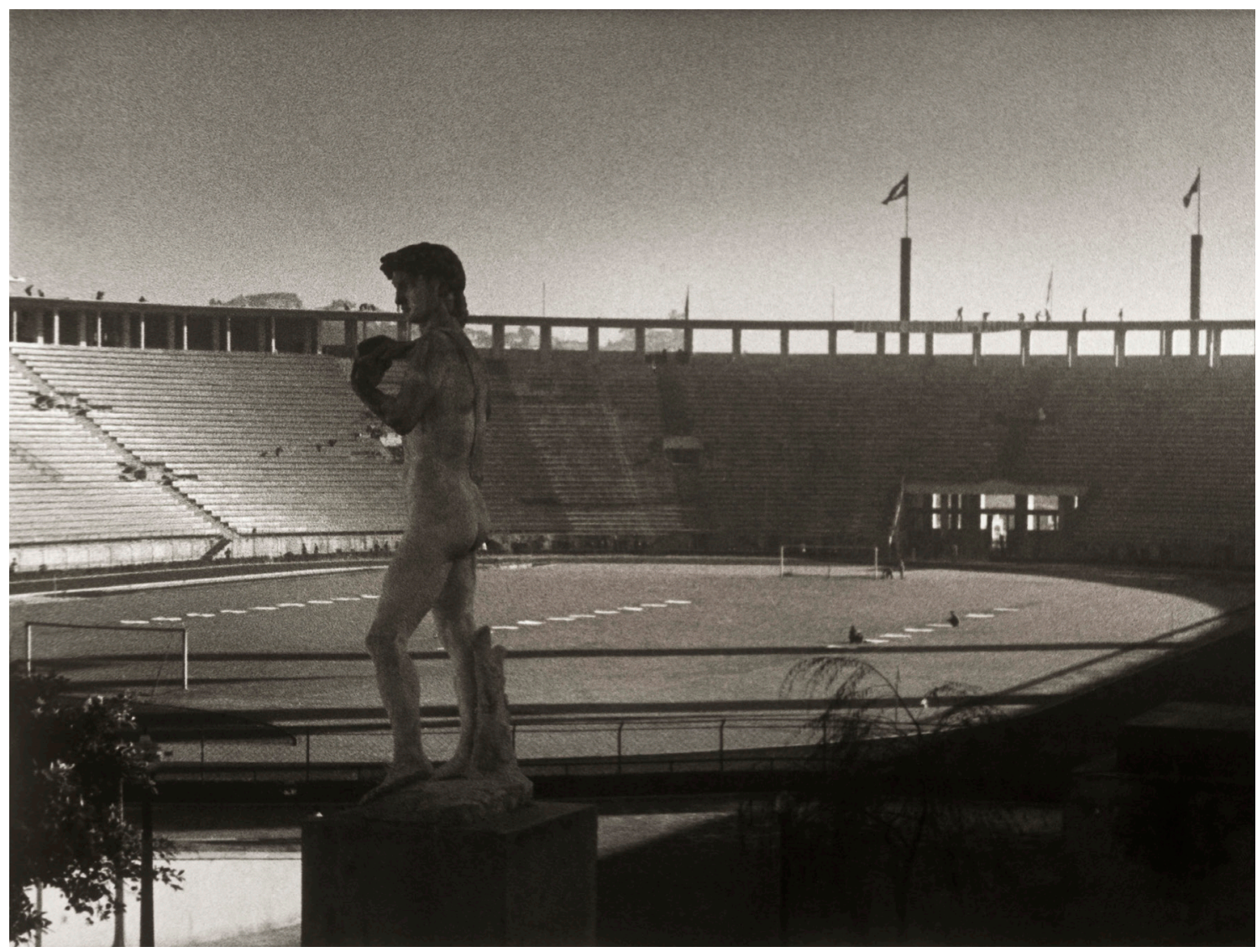

Estátua de Davi presente no estádio do Pacaembu, em São Paulo. Fonte: fotograma do filme Comício. Acervo da divisão de polícia política e social do Arquivo Público do Estado do Rio de Janeiro (APERJ).

Para pensar este filme como sendo um filme militante, diferenciando-o daqueles de propaganda, é necessário, finalmente, investigar o significado legítimo do termo militante. De acordo com o ensaio de Nelson Rosário de Souza (1999) sobre o surgimento da esquerda militante, o termo militante, que vem do latim militare, começou a ser empregado na linguagem teológica a partir da Idade Média. Naquele momento, o termo referia-se ao grau de envolvimento de um indivíduo com a Igreja no combate a seus inimigos de fé, podendo-se tomar como exemplo os calvinistas em sua defesa contra os católicos.

De acordo com a professora Adma Fadul Muhana (2003), estudiosa da prática jesuítica do padre Antônio Vieira, o emprego da expressão "igreja militante" nos séculos XVI e XVII fazia referência ao trabalho dos jesuítas em propagar a religião católica no Brasil com a perspectiva de conseguir torná-la uma igreja 
triunfante, depois de eliminar as demais como: judaísmo, maometistmo e o protestantismo, entre outras.

No século XVII, o termo militante passa ser usado também para definir o soldado da milícia que guerreia por uma causa já pré-determinada, quando a militância estaria, nesse caso, mais ligada à disciplina militar exigida do que a algo que se tem fé. Já no final do século XIX, com o aparecimento dos movimentos de esquerda, a ideia de militância aparece ligada a uma forma de envolvimento necessária à defesa dos grupos revolucionários: o ato de militar em um partido significava ter todo um comportamento disciplinado de maneira a conseguir suportar as constantes perseguições, onde o esquecimento de si em prol da causa revolucionária tornava-se necessário.

Podemos apontar aí para uma proximidade entre o sentido da militância religiosa, da militância militar e política, que é a que nos interessa aqui. O militante pode ser definido como aquele que defende ardorosamente uma causa, as ideias do grupo ao qual pertence e entra em combate para vê-la vitoriosa.

Enfim, no senso comum, ser militante de um partido exigia um grau de envolvimento que era sempre diferenciado em relação ao que seria apenas a atitude de um elemento simpatizante. Podemos dizer então que a existência de um cinema militante, portanto, faz referência à representação de grupos que não estão no poder instituído.

Importante observar que Ruy Santos tinha sido ao mesmo tempo do DIP e filiado ao PCB, mas suas inquietações sociais e políticas, como apontadas anteriormente por Hernani Heffner em relação ao curta Favela, potencializam sua veia militante. Ele não era simplesmente o cineasta do partido, mas comungava dos ideais do mesmo e, desta forma, tornou-se também um dos focos de vigilância da Polícia Política Brasileira. Sua prisão em 1948, mesmo que para “averiguações”, conforme justificado pela Polícia, fez com que muito da sua produção fotográfica fosse apreendida. O fotógrafo ficou detido somente uma noite, sendo solto no dia seguinte. Não sofreu tortura ou maus tratos, mas teve ser acervo perdido para sempre. Em entrevistas posteriores Ruy Santos chegou a comentar que esta prisão foi como "um balde de água fria" para sua carreira, visto que através do Partido Comunista estava deslanchando profissionalmente. 
Curioso observar que a Polícia passa de algoz a guardiã, pois o pouco do que restou da produção de Ruy Santos encontra-se no Arquivo Público do Estado do Rio de Janeiro (APERJ), hoje detentor de grande parte do acervo documental da polícia política brasileira. O material disponível no acervo do APERJ sobre o comício compõe-se, em sua maioria, de fotogramas do filme que, em função de seu arranjo, de sua identificação, enfim, de sua vida no arquivo, tornaram-se e foram vistas de maneira fixa, como fotografia.

O período democrático compreendido entre 1945 e 1947, durante o qual Ruy Santos trabalhou muito na documentação da história do partido, funcionou para a polícia política brasileira, de certa maneira, como uma oportunidade de conhecimento de líderes, membros e todos aqueles que saíram de um engajamento de surdina para mostrarem seus rostos, sua participação pública, uma vez que em 1948 o PCB estava de novo na ilegalidade.

As imagens e os filmes de Ruy Santos tornaram para a Polícia espécies de provas de atuação dos comunistas na cena social e política brasileira da época. Talvez tenha sido por isso que foram preservadas por todo este tempo. $\mathrm{O}$ trabalho de Ruy Santos no partido é anterior ao período democrático, como prova importante de sua atuação junto ao PCB, encontra-se a cobertura da Conferência da Mantiqueira, também conhecida como II conferência Nacional do PCB, realizada em agosto de 1943 no Rio de Janeiro e que não só marca a reorganização do PCB depois dos golpes sofridos até 1941, como aclama Prestes como secretário-geral do partido (enquanto esteve preso, até 1945, o posto foi ocupado por José Medina e Álvaro Ventura). É de Ruy Santos também a autoria do retrato do cavaleiro da esperança, realizado em 4 de abril de 1945, ainda quando detido na Penitenciária Central do Rio de Janeiro e utilizado em cartão de propaganda volante pela Comissão Pró-anistia a favor de Prestes. 


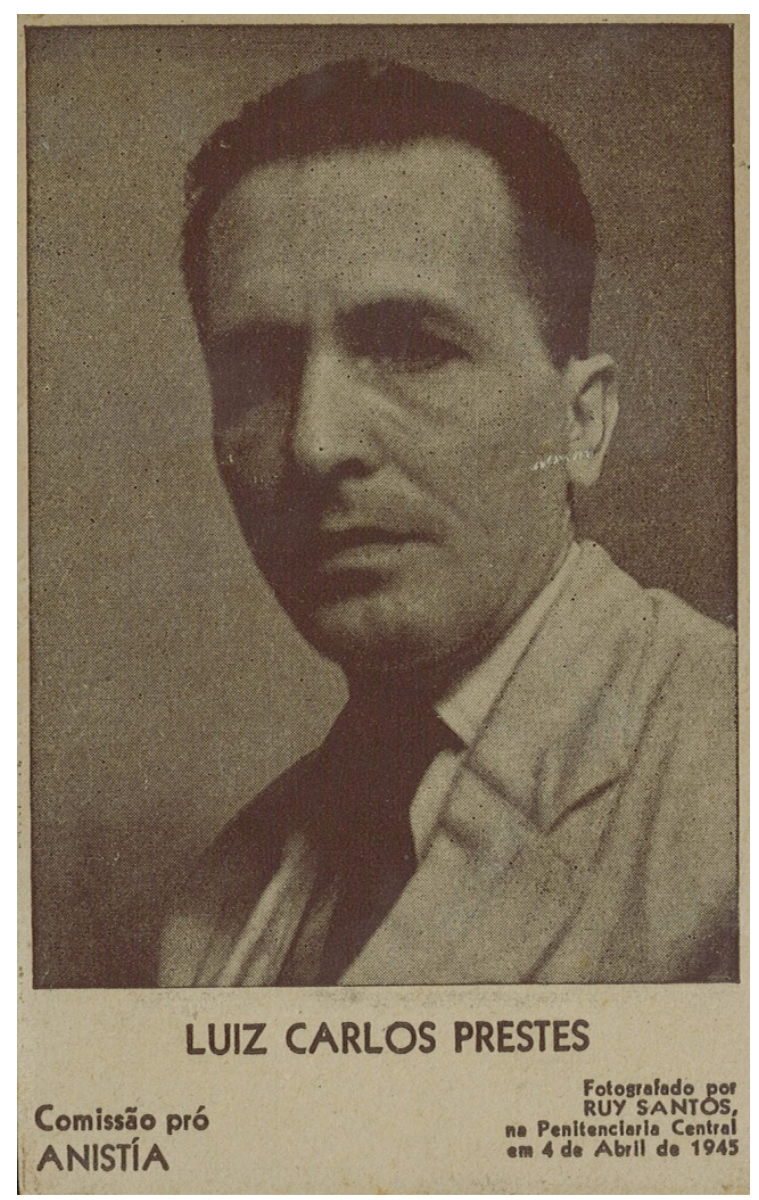

Cartão volante distribuído pela Comissão Pró-anistia. Foto de Ruy Santos. Fonte: Acervo da divisão de polícia política e social do Arquivo Público do Estado do Rio de Janeiro (APERJ).

É importante observar no lado inferior direito deste cartão a informação "fotografado por Ruy Santos na penitenciária Central em 4 de abril de 1945". Nota-se que não bastava trazer somente a imagem de Prestes, a chancela da autoria da imagem instiga um olhar engajado. A assinatura de Ruy Santos legitima ainda mais o retrato e firma seu nome no horizonte do partido. Era ele o nome da fotografia e do cinema no PCB neste período. Ele teve acesso a Prestes na cadeia e pôde fazer o retrato do grande líder. Não é à toa que a polícia política destaca que "ele privava da intimidade de Luiz Carlos Prestes". São muitos os retratos de Prestes encontrados no acervo cuja autoria é de Ruy Santos registrando Prestes em momentos familiares, protocolares, sociais, públicos. Mas o retrado indicado é especial pela condição da produção, pela importância do crédito, além da expressão cansada, um pouco triste, porém extremamente digna de Prestes. Esta 
imagem reflete o abatimento sofrido em função dos nove anos de prisão do então secretário nacional do Partido Comunista do Brasil, mas também o traduz com firmeza, fibra e coragem.

Ruy Santos era comunista e comungava, como muitos artistas e intelectuais da época, dos ideais e da perspectiva do PCB entrelaçando vida, obra e política. Graças ao documentário Vinte e quatro anos de lutas: como se formou o Partido Comunista do Brasil (1945), foi convidado a representar o Brasil como membro efetivo da diretoria da União Mundial dos Documentaristas, instituição já extinta, situada em Praga, Tchecoslovaquia. Esta informação a polícia também fez questão de recortar.

A imagem de Ruy Santos se forma nessa soma de forças com a policia, como também à sombra de um dos maiores inimigos que essa mesma policia já pôde ter: Luiz Carlos Prestes. Muitas das fotografias do Cavaleiro da Esperança foram feitas por Ruy Santos. E, por outro lado, o que lhe deu o maior prestigio no início de sua carreira, abriu caminhos e o impôs na política e no meio cinematográfico internacional foi o documentário Vinte e quatro anos de lutas: como se formou o Partido comunista do Brasil. Um filme que pôde ser visto somente pelos contemporâneos. Foi rodado em 1945 e, para ele, Ruy Santos também filmou Prestes ainda na cadeia. Houve algumas sessões públicas, mas o documentário está desaparecido desde 1947, quando foi apresentado ao Serviço de Censura da Divisão de Diversões Públicas, visando obter licença de exibição, jamais obtida. O que restou dele foi somente o roteiro, arquivado no APERJ, junto ao prontuário de Luiz Carlos Prestes. O filme foi feito através da produtora cinematográfica do Partido Comunista, a Liberdade Filmes. Com tom heroico, bem próprio do realismo socialista, o filme realça o aspecto grandioso do grande espetáculo político-partidário que o PCB estava interessado em difundir naquele momento.

O Partido Comunista permitiu a Ruy Santos adquirir notoriedade internacional como fotógrafo e cineasta, mas sua relação política e ideológica com os ideais do comunismo vinham de longe. Oriundo de família comunista, teve mãe militante. Casou-se com Geny, cujos pais eram russos, comunistas e vieram para o Brasil no início do século XX. Os ideais comunistas eram, para ele, quase que "atávicos", se é que podemos falar assim. Em uma de suas declarações para o pesquisador e cineasta Alex Viany, numa série de entrevistas que este promoveu com cineastas 
brasileiros (VIANY, 1980) ${ }^{10}$, ele diz que: "todo cineasta deve situar sua obra frente à realidade que vive e que o mais importante é fazer filmes que se comuniquem com o grande público, fazendo com que ele participe daquilo que está vendo, sem ser panfletário ou demagógico".

Esta declaração é importante porque, em certa medida, aponta uma das facetas de Ruy Santos que podem ser evidenciadas em sua obra de um modo geral: a relação com o povo, por onde podemos apontar seu caráter político que emerge das fotografias encontradas no acervo, neste recorte temporal de 15 de julho de 1945, data de realização do comício São Paulo a Luiz Carlos Prestes.

Por ser fotógrafo e por ser cineasta, torna-se interessante promover aproximações e distanciamentos estéticos e políticos para podermos localizar sua produção e tentarmos compreender suas marcas e influências.

Uma faceta de Ruy Santos que poderia situá-lo entre o literário, o político e o estético com uma forte influência do realismo socialista seria sua aproximação com as obras do escritor russo Máximo Gorki (1868 - 1936), do qual adaptou para o cinema o conto Onde a terra começa (1965). Gorki foi um dos autores do manifesto do realismo socialista, estilo artístico aprovado pelo regime comunista da ex-URSS, por ocasião do $1^{\circ}$ Congresso de Escritores Soviéticos, em 1934.

Entre 1930 e 1950 o realismo socialista torna-se arte oficial, referendando a linha ideológica do Partido Comunista. Seus preceitos mais importantes normatizam que teatro, literatura e artes visuais deveriam ter um compromisso primeiro com a educação e formação das massas para o socialismo em construção no país. A arte deveria ser "proletária e progressista", empenhada politicamente, envolvida com os temas nacionais e com as questões do povo russo. Isso significa que a obra de arte deveria ser acessível ao povo e instrumento de propaganda do regime. Nada de abstracionismos, mas sim figurativismo.

Desenhos, telas e cartazes publicitários devem mostrar proletários, camponeses, soldados, líderes como heróis nacionais, muitas vezes em celebrações de movimentos sociais e feitos políticos. O intuito é o de louvor à nova sociedade. A União Soviética exportou o realismo socialista a quase todos os demais estados socialistas, onde a doutrina foi sendo cobrada em 
ano 2 número 3

Dossiê

diversos graus de rigor, convertendo-se na forma predominante de arte nesses países durante cerca de cinquenta anos. O PCB endossou esta orientação e Ruy Santos a espelha em seu trabalho.

Ainda de acordo com a pesquisadora e professora de cinema Hilda Machado, num dos poucos artigos existentes publicados sobre Ruy Santos "Ruy era a própria história da nossa fotografia de cinema e era um comunista que gostava de Godard". Da nouvelle vague percebemos a força da narrativa a partir da imagem, o tempo mais lento para que seja mostrada, os contra-plongées, o "fazer cinema" com a fotografia. Ruy Santos reunia, assim, um ecletismo singular que nos dá pistas de como olhar para os mais de cinqüenta filmes produzidos (entre documentários e ficção) ao longo de quase sessenta anos de cinema.

\section{O olhar fotográfico do cineasta na construção do filme Comício: São Paulo a Luiz Carlos Prestes}

No filme Comício: São Paulo a Luiz Carlos Prestes ${ }^{11}$, Ruy Santos busca dar um tratamento mais apurado às imagens, mas fica visível a utilização da linguagem do cinejornal vigente na época. O cineasta narra dos preparativos à realização do comício no Pacaembu. Em prol do seu objetivo, grava cenas da cidade de São Paulo, evidenciando a capital paulista como grande metrópole. Na sede do Partido Comunista paulista capta o trabalho de produção do evento. Costureiras, pintores, secretárias, militantes, todos buscam contribuir com o acontecimento.

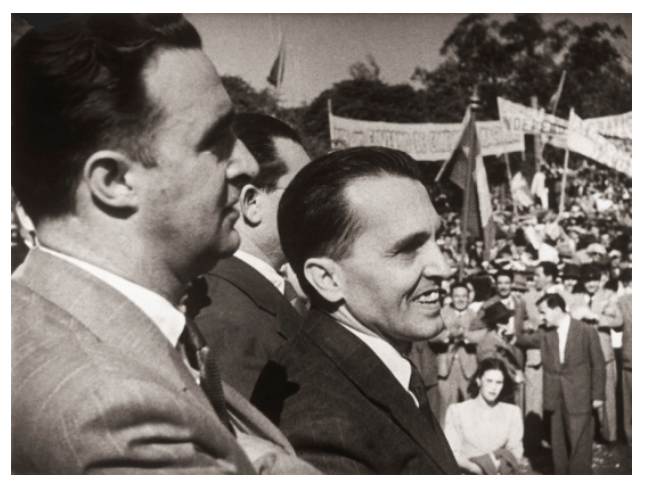

Luiz Carlos Prestes em desfile no estádio do Pacaembu. Fotograma do filme Comício: São Paulo a Luiz Carlos Prestes. Fonte: Acervo da divisão de polícia política e social do Arquivo Público do Estado do Rio de Janeiro (APERJ). 


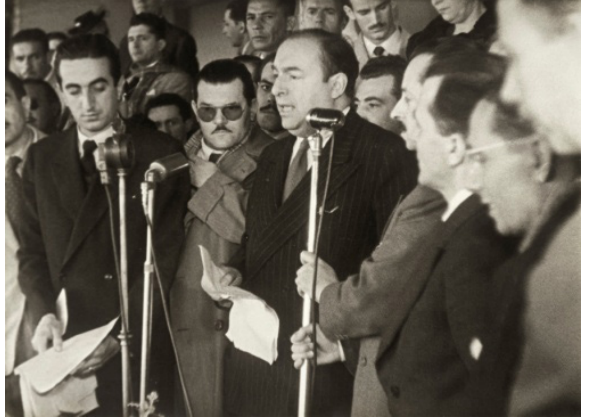

Pablo Neruda discursando no Comício de Luiz Carlos Prestes no Pacaembu. Fotograma do filme Comício. Fonte: Acervo da divisão de polícia política e social do Arquivo Público do Estado do Rio de Janeiro (APERJ).

Já o roteiro do longa-metragem Vinte e quatro anos de lutas supõe-se provavelmente a utilização do mesmo plano-sequência do curta, porém com aproveitamento de menos imagens. Assim está previsto no roteiro:

Letreiro Pacaembu. A entrada de Prestes no Pacaembu assume proporções inéditas, pela sua beleza e grandiosidade. A multidão de trabalhadores, de camponeses, de velhas e jovens, de homens e mulheres, de todas as classes vibra de entusiasmo e emoção com a presença de Prestes (ROTEIRO, 1947).

No curta, o estádio é mostrado vazio e depois, aos poucos, a multidão vai ordenadamente desfilando pelas laterais e ocupando os espaços nas arquibancadas. Nele também, um narrador ora interpreta as imagens mostradas, ora oferece informações adicionais sobre elas. Essa é uma marca do rádio que imprime ao cinema da época a voz, o imaginar a imagem, ao invés de vê-la.

Já no longa, o roteiro do filme tem sete partes. A primeira indicação, logo após o titulo, é de cenas de camponeses. Depois, logo na primeira cena, está previsto "esta é a casa onde reside atualmente o escritor Astrogildo Pereira, um dos fundadores do Partido Comunista" e durante todo o roteiro o narrador vai conduzindo as imagens, muitas vezes, fotografias. As imagens do comício do Pacaembu são marcantes e é com elas que o longa termina ao som do discurso de Luiz Carlos Prestes gravado em estúdio: 
O partido é como um rio cujas águas se avolumam à medida que os anos correm. O delicado rio que se formou há 24 anos é hoje uma torrente. Inútil pretender estancar essa corrente porque sua fonte é o proletariado, são as grandes massas, é o povo. Mais e mais ele cresce e aprofunda seu leito e irriga novas terras onde crescerá a democracia e uma nova vida de progresso surgirá (ROTEIRO, 1947, p. 123).

As 45 fotos do comício do Pacaembu - sob os cuidados do APERJ traduzem um enfoque do realismo socialista, fazendo do povo objeto de sua cena, tornando-o glorioso como ponto de vista e se preocupando com o acompanhamento real de seus personagens. Havia naquelas imagens um olhar cuidado, uma preocupação com a técnica e a forma da fotografia moderna, assim como as pessoas assumiam uma importância de protagonistas das cenas. Olhavam deliberadamente para a câmera que nunca está escondida, pelo contrário, faz questão de ser evidenciada a cada fotograma.

Diante dessas imagens vale conjurar aqui as ressalvas do russo Tretiakov que, na década de 1930, na Rússia, travou com o artista Alexander Rodchenko uma polêmica pública em torno das fotografias a serem produzidas em prol do regime comunista. Tretiakov argumenta sobre o ponto de vista funcional do fotógrafo dando como exemplo a fotografia de uma manifestação.

O ponto de vista adotado depende do objetivo pretendido: se a ênfase recair na multidão, dever-se-á fotografar verticalmente, em ângulo superior. Se quiser mostrar-se a composição social da multidão, será necessário fotografar diretamente, escolhendo ângulos que deem a ver a profissão das pessoas pelas roupas e recorrendo a primeiros planos. Se o foco for o avanço impetuoso da manifestação, os pés serão o elemento mais importante da imagem.

Deve-se, ainda, optar pelo ângulo inclinado para criar "a ilusão da emanação de uma lava humana (uma indicação puramente estética)" (FABRIS, 2005). Se o objetivo for mostrar as exigências da manifestação, será necessário fotografar os cartazes na escala mais ampla possível, deixando bem nítidos seus dizeres. Se quiser reproduzir-se a massa humana cristalizada em volta de uma força 
central, poderá ser usada uma exposição dupla: à fotografia da manifestação em ângulo superior será acrescentada a imagem de uma construção análoga (um formigueiro, abelhas num favo de mel, os anéis de um tronco etc).

O povo está em evidência nos discursos, nas faixas e como sujeito/objeto das imagens, proporcionando elementos visuais que evidenciam seu grau de importância naquele momento da história. Ruy Santos enquadra a multidão, ordena as delegações, registra a profusão de faixas com os dizeres: "o povo quer eleições". De abstrato e anônimo, nas imagens de Ruy Santos, o povo tem rosto, come, desfila, espera e lê a Tribuna Popular, enquanto aguarda o discurso dos líderes.

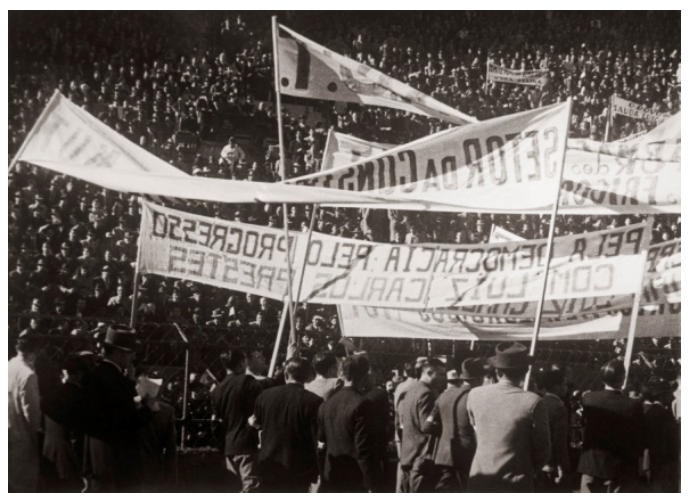

Participantes do evento. Fotograma do filme Comício. Acervo da divisão de polícia política e social do Arquivo Público do Estado do Rio de Janeiro (APERJ).

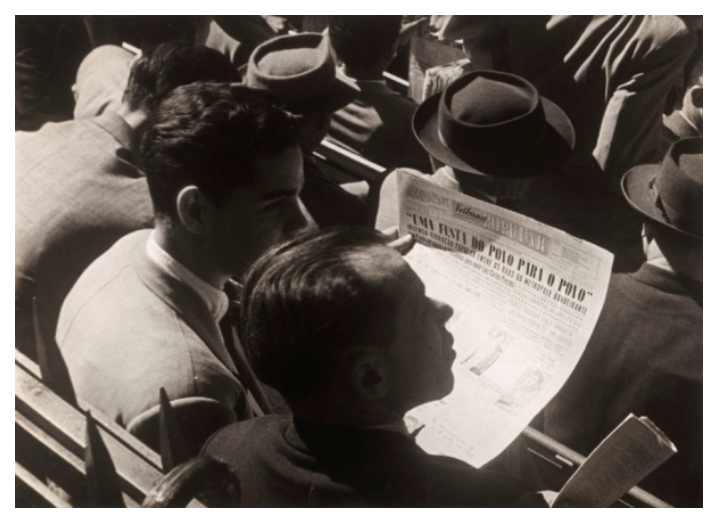

Homens leem a Tribuna Popular durante o evento. Acervo da divisão de polícia política e social do Arquivo Público do Estado do Rio de Janeiro (APERJ). 
ano 2 número 3

Dossiê

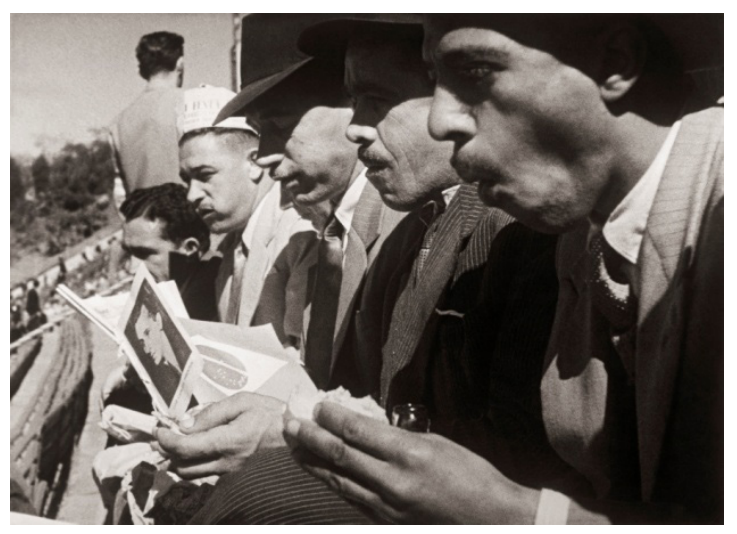

Trabalhadores comem enquanto esperam os discursos. Fotograma do filme Comício. Acervo da divisão de polícia política e social do Arquivo Público do Estado do Rio de Janeiro (APERJ).

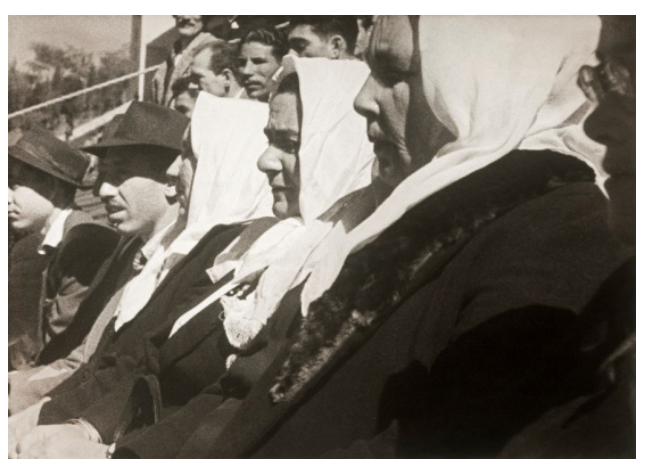

Camponesas à espera dos discursos. Fotograma do filme Comício Acervo. Acervo da divisão de polícia política e social do Arquivo Público do Estado do Rio de Janeiro (APERJ).

A plasticidade das imagens de Ruy Santos é construída com linhas definidas, claro-escuro acentuado e controle da luz dura, numa tentativa de dotar a cena de forte traço geométrico. O grafismo da arquibancada vazia se mantém no desfile das delegações empunhando faixas e orquestrando movimentos sinuosos em seu desfile pelo estádio do Pacaembu, tendo ao fundo o grande retrato do líder. 


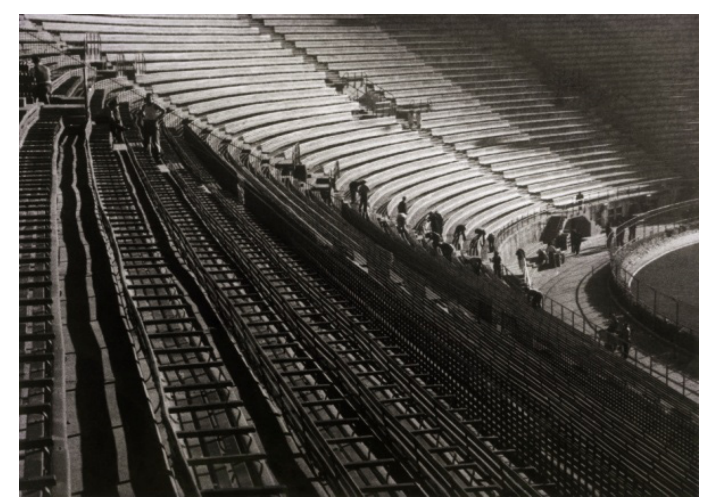

Pacaembu antes do comício, em preparativos. Fotograma do filme Comício. Acervo da divisão de polícia política e social do Arquivo Público do Estado do Rio de Janeiro (APERJ).

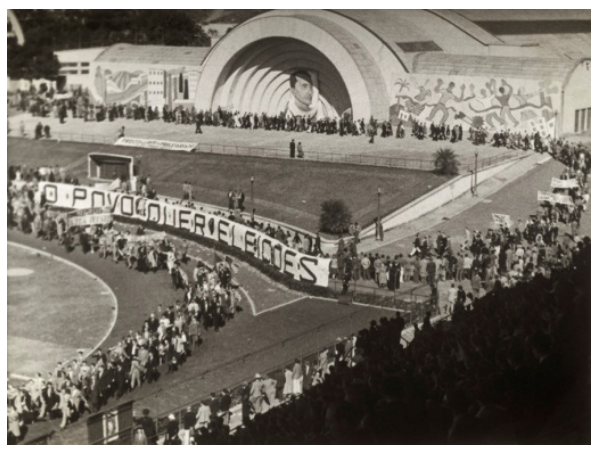

Desfile das delegações no início do comício. Fotograma do filme Comício. Acervo da divisão de polícia política e social do Arquivo Público do Estado do Rio de Janeiro (APERJ).

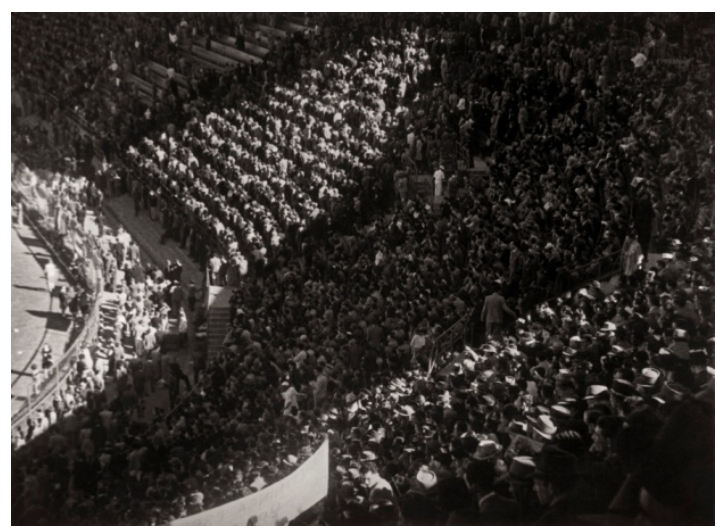

Arquibancada cheia. Fotograma do filme Comício. Acervo da divisão de polícia política e social do Arquivo Público do Estado do Rio de Janeiro (APERJ). 
O contraluz e a geometrização o aproximam da fotografia moderna brasileira, uma certa concepção de fotografia que nasce no começo do século XX, no seio das vanguardas europeias e que no Brasil tomou corpo sobretudo no interior do movimento fotoclubista a partir de meados da década de 40. Teve como pioneiros José Yalenti, Thomas Farkas, Geraldo de Barros e German Lorca e expressão máxima na obra de Geraldo de Barros e José Oiticica filho ${ }^{12}$.

Hilda Machado polemiza ainda ao falar de Ruy Santos ao dizer que "suas imagens não devem nada às dos mauricinhos" ${ }^{\prime 13}$. Suas fotografias se aproximam também do trabalho da fotógrafa comunista italiana Tina Modotti, que ganhou notoriedade com suas imagens de camponeses e comunistas mexicanos nos anos 20 e 30. As imagens promovem encontros estéticos profícuos entre Ruy Santos, Farkas e Modotti, em que momentos de equilíbrio de composição são registrados com sensibilidade pelos três fotógrafos que possuem biografias muito diferentes e que nem sempre os aproxima politicamente.

Entre os curtas-metragens, dirigiu e fotografou Áreas Verdes (1974), Pinheirais (1974), Teatro (1974), Pelos caminhos do Tear (1975), O homem e o limite (1976), O Pequeno Mundo de Juca (1964) e Delmiro Gouveia (1968), sendo que dos dois últimos foi também produtor e roteirista.

Ruy Santos fez de tudo um pouco no cinema e reúne em sua bagagem quase uma centena de filmes entre curta, média e longa metragem, dos mais variados gostos e tendências. Ficou famoso por suas filmagens em exteriores. Seu olhar era impregnado de paixão e lirismo, um verdadeiro poeta da imagem. Mas se nos atermos ao trabalho de Ruy Santos como cineasta, atuante já há duas gerações antes do Cinema Novo, não compreendemos porque seu nome não frequentou as produções de Glauber Rocha e Nelson Pereira dos Santos, entre outros.

12. Para maiores informações consultar o livro de Renato Rodrigues e Helouise Costa A fotografia moderna no Brasil, publicado em 1996 (Funarte/UFRJ) a partir de texto realizado em 1987. Ele estabelece como um marco da experiência moderna brasileira em fotografia a Escola Paulista, denominação que agrupa participantes que frequentaram por um breve período durante anos 50 o conjunto de atividades ao redor do Foto Cine Clube Bandeirante (1939). 
De acordo com Hernani Heffner, esta ausência se justifica pelo não enquadramento de Ruy Santos à estética cinemanovista da câmera nua. Ruy Santos era um cineasta que prezava sobretudo os filtros, a composição da imagem com a luz e não se dobrava ao despojamento da imagem. Apesar de ser um dos primeiros a anunciar questões políticas no cinema, não teve seu nome associado aos grandes nomes do cinema novo e tampouco era convidado para participar das produções como bom diretor de fotografia que foi e sendo marcante na história da cinematografia brasileira.

Ruy Santos pode, então, ser visto assim entre o político e o estético, apresentando a luz como grande marca de seu olhar. Para o fotógrafo francês naturalizado americano, Edouard Steichen, que também tinha sua composição marcada pela luz, "ela é uma charlatã", que tem o poder de trapacear a realidade, criando imagens que desvirtuam o referente do real e, com isso, é capaz de criar uma nuvem de ficção para seus retratados. Para Ruy Santos, a luz é matéria-prima para realçar sua concepção documental da cena e trazer para o espectador um real menos trapaceado, mas nem por isso nu. E, com sua estética, contribuiu para a produção do cinema militante, deixando gravado um dos momentos políticos mais férteis da esquerda brasileira. 


\section{Referências}

AUTRAN, A. "Ruy Santos". In: RAMOS, Fernão; MIRANDA, Felipe Luís (org.). Enciclopédia do Cinema Brasileiro. São Paulo: Editora SENAC, 2000. p. 640-641.

BERNARDET, J-C. Cineastas e Imagens do Povo. São Paulo: Editora Cia. das Letras, 2003. . Cinema brasileiro: propostas para uma história. Rio de Janeiro: Paz e Terra, 1979.

DA-RIN, S. O espelho partido: tradição e transformação do documentário cinematográfico. Rio de Janeiro: Azougue, 2004.

FABRIS, A. "Entre arte e propaganda. Fotografia e fotomontagem na vanguarda soviética". Anais do Museu Paulista, jan.-jun., 2005. Vol 13, n.1. Universidade de São Paulo. p. 99-132. Disponível em :http://redalyc.uaemex.mx/pdf/273/27313104.pdf

FARKAS, T. Pacaembu. São Paulo: Editora DBA, 2008.

FOUCAULT, M. Vigiar e punir: nascimento da prisão. Petrópolis: Vozes, 1987.

MACHADO, H. "Além da ficção: cinema de não ficção no Brasil". In: Revista Alceu. V.8, n.15. Jul.-dez. 2007. p. 331-339. Disponível em http://publique.rdc.puc-rio.br/revistaalceu/media/ Alceu_n15_Machado2.pdf . "Algumas perguntas a fotogramas de Ruy Santos". Cinemais: revista de cinema e outras questões audiovisuais. Rio de Janeiro, v. 35, p. 196-207, 2003.

MENDONÇA, E. R. F. de. Documentação da Polícia Política do Rio de Janeiro. Revista Estudos Históricos. Rio de Janeiro, vol. 12, n.22, 1998.

MOTTA, R. P. S. Em guarda contra o "Perigo Vermelho": o anticomunismo no Brasil (1917 1964). São Paulo: Perspectiva: FAPESP, 2002.

MUHANA, A. F. “Brasil: Índia Ocidental”. In: Revista USP. São Paulo, n.57, p. 38-49, mar.mai. 2003.

NICHOLS, B. Introdução ao documentário. Campinas: Papiros Editora, 2005. 
PANDOLFI, D. Camaradas e companheiros: memória e história do PCB. Rio de Janeiro: Relume Dumará, 1995.

RAMOS, F.; MIRANDA, L. F. (org.). Enciclopédia do Cinema Brasileiro. São Paulo: Editora SENAC, 2000.

RAMOS, F. Mas afinal...o que é mesmo documentário? São Paulo: Editora SENAC, 2008.

RODCHENKO, A. "Against the synthetic portrait, for the snapshot". In: Photography in the modern era: european documents and critical writings, 1913-1940. New York: MOMA, 1989.

RUBIM, A. A. C. "O partido comunista e o cinema no Brasil". Caderno de crítica. N. 5. Rio de Janeiro. Fundação do Cinema Brasileiro, 1988.

SANTOS, R. Comício: São Paulo a Luís Carlos Prestes. Filme. Rio de Janeiro: Estúdio Cinédia, 1945.

SEGATTO, J. A.; NETTO, J. P.; NÉTO, J. R.; AZEVEDO, P. C.; SACCHETTA, V. PCB Memória fotográfica: 1922 - 1982. São Paulo: Editora Brasiliense, 1982.

SOUSA, A. C. C. Comício: São Paulo a Luís Carlos Prestes - o Partido Comunista e o cinema. Disponível em www.historia.uff.br/nec/textos/.

SOUZA, N. R. "A esquerda militante: entre o engajamento pastoral e os revides locais". Revista de Sociologia e Política. Jun., n.12, 1999. p.131-146.

TEIXEIRA, F. E. (org.). Documentário no Brasil, tradição e transformação. São Paulo: Summus, 2000.

VIANY, A. Ruy Santos Entrevista. Rio de Janeiro, 30 set. 1980. Transcrição. Disponível em www.alexviany.com.br. 